Nevada

Environmental

Restoration

Project

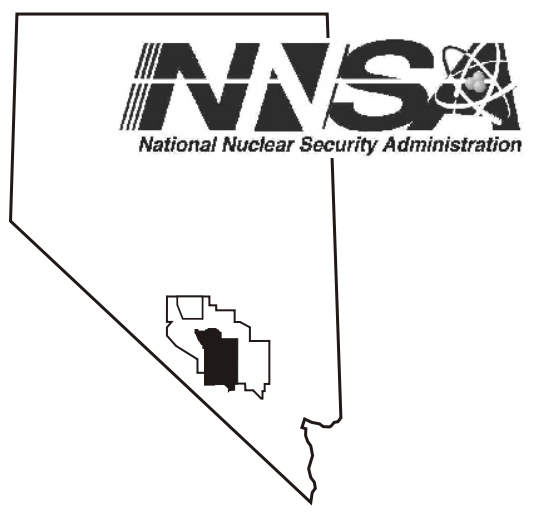

\title{
Closure Report for Corrective Action Unit 286: Lead/Chemical/Spill Sites, and Material Dumps, Nevada Test Site, Nevada
}

Controlled Copy No.:

Revision: 0

August 2005

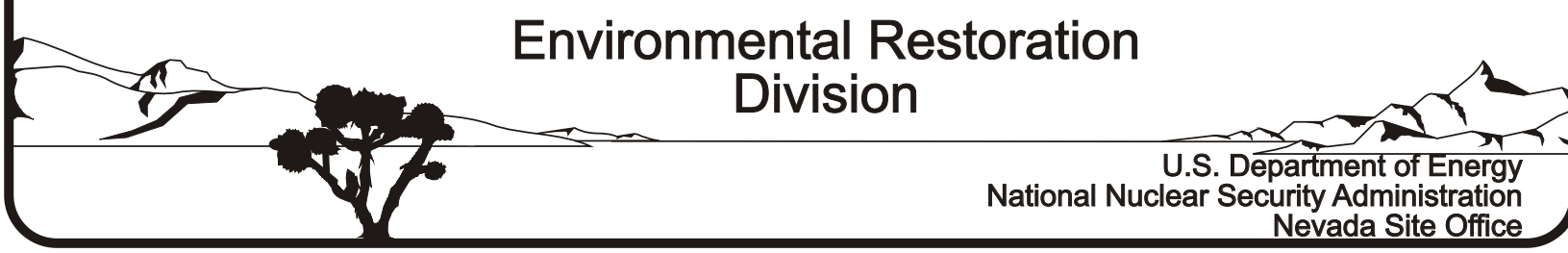




\title{
DISCLAIMER
}

This report was prepared as an account of work sponsored by an agency of the U.S. Government. Neither the U.S. Government nor any agency thereof, nor any of their employees, nor any of their contractors, subcontractors or their employees, makes any warranty or representation, express or implied, or assumes any legal liability or responsibility for the accuracy, completeness, or usefulness of any information, apparatus, product, or process disclosed, or represents that its use would not infringe privately own rights. Reference herein to any specific commercial product, process, or service by trade name, trademark, manufacturer, or otherwise, does not necessarily constitute or imply its endorsement, recommendation, or favoring by the U.S. Government or any agency thereof. The views and opinions of authors expressed herein do not necessarily state or reflect those of the U.S. Government or any agency thereof.

This report has been reproduced directly from the best available copy.

Available for sale to the public from:

\author{
U.S. Department of Commerce \\ National Technical Information Service \\ 5285 Port Royal Road \\ Springfield, VA 22161-0002 \\ Telephone: (800) 553-6847 \\ Fax: (703) 605-6900 \\ E-mail: orders@ntis.gov \\ Online ordering: http://www.ntis.go v/ordering.htm
}

Available electronically at http://www.osti.gov/bridge.

Available for a processing fee to the U.S. Department of Energy and its contractors, in paper, from:

U.S. Department of Energy

Office of Scientific and Technical Information

P.O. Box 62

Oak Ridge, TN 37831-0062

Telephone: (865) 576-8401

Fax: (865) 576-5728

E-mail: reports@adonis.osti.gov 


\title{
CLOSURE REPORT FOR CORRECTIVE ACTION UNIT 286: LEAD/CHEMICAL/SPILL SITES AND MATERIAL DUMPS, NEVADA TEST SITE, NEVADA
}

\author{
U.S. Department of Energy \\ National Nuclear Security Administration \\ Nevada Site Office \\ Las Vegas, Nevada
}

Controlled Copy No:

Revision: 0

August 2005 
THIS PAGE INTENTIONALLY LEFT BLANK 


\section{CLOSURE REPORT FOR CORRECTIVE ACTION UNIT 286: \\ LEAD/CHEMICAL/SPILL SITES AND MATERIAL DUMPS, NEVADA TEST SITE, NEVADA}

Approved By: SIGNATURE APPROVED

Date:

Sabine Curtis, Acting Project Manager

Industrial Sites Project

Approved By: SIGNATURE APPROVED

Date: 
THIS PAGE INTENTIONALLY LEFT BLANK 


\section{TABLE OF CONTENTS}

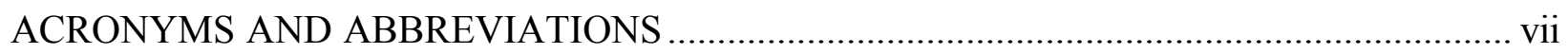

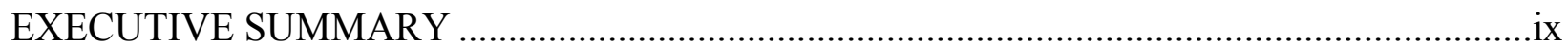

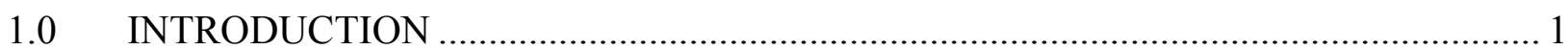

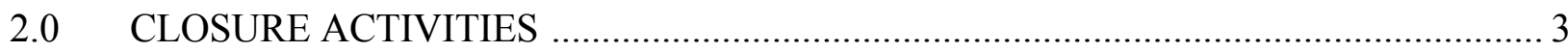

$2.1 \quad$ DESCRIPTION OF CLOSURE ACTIVITIES ………................................................. 3

2.1.1 Preplanning and Site Preparation ....................................................... 3

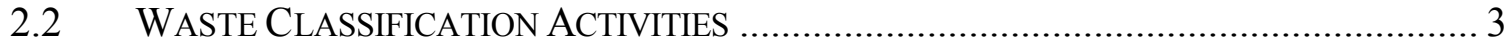

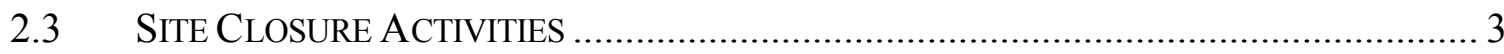

2.3.1 CAS 01-26-02: Lead Sheets; Lead Lined Pit ......................................... 3

2.3.2 CAS 02-26-02: Lead Pipes/RAD Area...................................................... 3

2.3.3 CAS 02-26-10: Lead Shot ……………..................................... 4

2.3.4 CAS 02-99-06: Material Dump …………........................................ 4

2.3.5 CAS 03-25-02: Oil Spills ................................................................. 4

2.3.6 CAS 03-29-01: Methyl Alcohol Bottle ………………………............... 4

2.3.7 CAS 03-29-02: Acid Box; Chemicals ……............................................ 4

2.3.8 CAS 04-99-03: Oil (Quart)............................................................... 4

2.3.9 CAS 06-14-01: Radiation Counting Shield (Lead) …………………..... 4

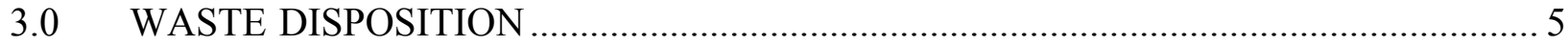

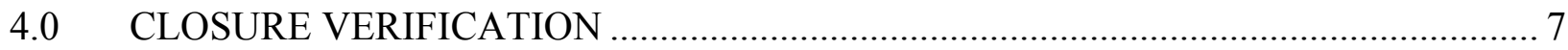

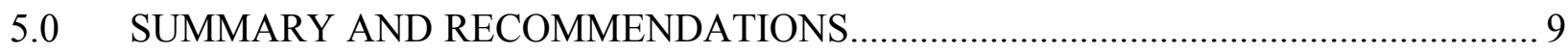

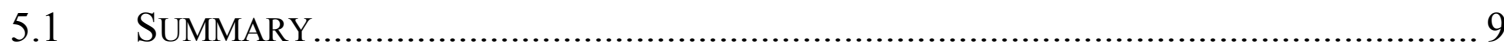

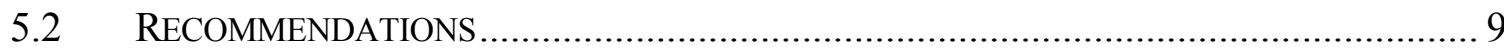

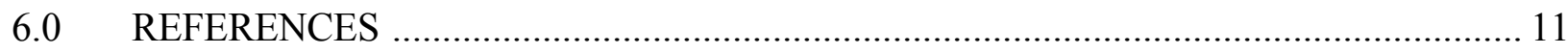

\section{FIGURES}

FIGURE 1. CAU 286 SITE LOCATION MAP …………......................................................... 2

\section{TABLES}

TABLE 1. SUMMARY OF ANALYTICAL RESULTS FOR VERIFICATION SAMPLES. 


\section{TABLE OF CONTENTS (continued)}

\section{APPENDICES}

APPENDIX A: SAMPLE ANALYTICAL RESULTS

A-1

APPENDIX B: SECTORED HOUSEKEEPING SITE CLOSURE

VERIFICATION FORMS. B-1

APPENDIX C: NATIONAL ENVIRONMENTAL POLICY ACT

EVALUATION CHECKLIST C-1

APPENDIX D: FFACO CORRESPONDENCE D- 1

LIBRARY DISTRIBUTION LIST 


\section{ACRONYMS AND ABBREVIATIONS}

$\begin{array}{ll}\text { BN } & \text { Bechtel Nevada } \\ \text { CAS } & \text { Corrective Action Site } \\ \text { CAU } & \text { Corrective Action Unit } \\ \text { EPA } & \text { U.S. Environmental Protection Agency } \\ \mathrm{ft} & \text { foot (feet) } \\ \mathrm{ft}^{3} & \text { cubic foot (feet) } \\ \text { FFACO } & \text { Federal Facility Agreement and Consent Order } \\ \mathrm{mg} / \mathrm{kg} & \text { milligram(s) per kilogram } \\ \mathrm{NDEP} & \text { Nevada Division of Environmental Protection } \\ \mathrm{NNSA} / \mathrm{NSO} & \begin{array}{l}\text { U.S. Department of Energy, National Nuclear Security Administration } \\ \text { Nevada Site Office }\end{array} \\ \mathrm{PRG} & \text { Preliminary Remediation Goal(s) } \\ \mathrm{Rd}^{3} & \begin{array}{l}\text { radiation } \\ \text { cubic yard(s) }\end{array}\end{array}$


Closure Report - CAU 286

Section: Acronyms \& Abbr

Revision: 0

Date: August 2005

THIS PAGE INTENTIONALLY LEFT BLANK 


\section{EXECUTIVE SUMMARY}

Corrective Action Unit (CAU) 286 consists nine Corrective Action Sites (CASs) located in Areas 1, 2, 3, 4, and 6 of the Nevada Test Site. The closure activities performed at each CAS are listed below.

- $\quad$ CAS 01-26-02, Lead Sheets; Lead Lined Pit: Clean-closed with no further action necessary.

- CAS 02-26-02, Lead Pipes/RAD Area: Clean-closed with no further action necessary.

- CAS 02-26-10, Lead Shot: Clean-closed with no further action necessary.

- CAS 02-99-06, Material Dump: Clean-closed with no further action necessary.

- CAS 03-25-02, Oil Spills: Clean-closed with no further action necessary.

- CAS 03-29-01, Methyl Alcohol Bottle: No action taken, because debris had been previously removed.

- CAS 03-29-02, Acid Box; Chemicals: No action taken, because debris had been previously removed.

- CAS 04-99-03, Oil (Quart): No action taken due to inaccessability of identified oil can.

- CAS 06-14-01, Radiation Counting Shield (Lead): No action taken, because debris had been previously removed.

Five CASs that were originally part of CAU 286 were transferred out of CAU 286 and into CAU 5000. The transfers were approved by the Nevada Division of Environmental Protection and copies of the approval letters are included in Appendix D of this report. The following five CASs were transferred out of CAU 286 and into CAU 5000 on the dates indicated:

- CAS 02-26-01, Lead (Concrete Box w/Lining), on December 2, 2004

- CAS 02-26-07, Gun Turret w/Lead in Barrel, on May 4, 2004

- CAS 04-26-02, Lead on Instrument Bunker, on December 2, 2004

- CAS 10-23-01, Metal Debris (RAD), on May 24, 2005

- CAS 18-99-08, Cores in Boxes, on May 24, 2005

Note: CAS 10-23-01 and 18-99-08 were originally part of CAU 210 and CAU 167 respectively. These CASs were transferred into CAU 286 on April 15, 2004 and were subsequently transferred to CAU 5000 on May 24, 2005. 
Closure Report - CAU 286

Section: Executive Summary

Revision: 0

Date: August 2005

THIS PAGE INTENTIONALLY LEFT BLANK 


\subsection{INTRODUCTION}

This report documents that the closure activities conducted for Corrective Action Unit (CAU) 286: Lead/Chemical/Spill Sites and Material Dumps met the approved closure standards. CAU 286 is listed in Appendix III of the Federal Facility Agreement and Consent Order

(FFACO, 1996) and consists of nine Corrective Action Sites (CAS) located in Areas 1, 2, 3, 4, and 6 of the Nevada Test Site (Figure 1):

- $\quad$ CAS 01-26-02 Lead Sheets; Lead Lined Pit

- CAS 02-26-02 Lead Pipes/RAD (radiation) Area

- CAS 02-26-10 Lead Shot

- CAS 02-99-06 Material Dump

- CAS 03-25-02 Oil Spills

- CAS 03-29-01 Methyl Alcohol Bottle

- CAS 03-29-02 Acid Box; Chemicals

- CAS 04-99-03 Oil (Quart)

- CAS 06-14-01 Radiation Counting Shield (Lead)

At three of the CASs, it was documented that the waste had been previously removed from the site. One additional CAS no longer had waste onsite. However, due to the availability of photographs showing the exact location of the former waste, verification samples were collected. Closure activities at the remaining CASs consisted of documenting current site conditions, identifying and removing debris and contaminated soil, classifying and disposing of the generated waste, collecting and analyzing soil verification samples, and verifying by visual inspection that each site was clean of debris.

Copies of analytical results for verification samples are included in Appendix A. Copies of the "Sectored Hous ekeeping Site Closure Verification Forms" are included in Appendix B. A copy of the "National Environmental Policy Act Evaluation Checklist" for CAU 286 is included in Appendix C.

Five CASs that were originally part of CAU 286 were transferred out of CAU 286 and into CAU 5000. The transfers were approved by the Nevada Division of Environmental Protection and copies of the approval letters are included in Appendix D of this report. The following five CASs were transferred out of CAU 286 and into CAU 5000 on the dates indicated:

- $\quad$ CAS 02-26-01, Lead (Concrete Box w/Lining), on December 2, 2004

- CAS 02-26-07, Gun Turret w/Lead in Barrel, on May 4, 2004

- CAS 04-26-02, Lead on Instrument Bunker, on December 2, 2004

- CAS 10-23-01, Metal Debris (RAD), on May 24, 2005

- CAS 18-99-08, Cores in Boxes, on May 24, 2005

Note: CAS 10-23-01 and 18-99-08 were originally part of CAU 210 and CAU 167 respectively. These CASs were transferred into CAU 286 on April 15, 2004 and were subsequently transferred to CAU 5000 on May 24, 2005. 


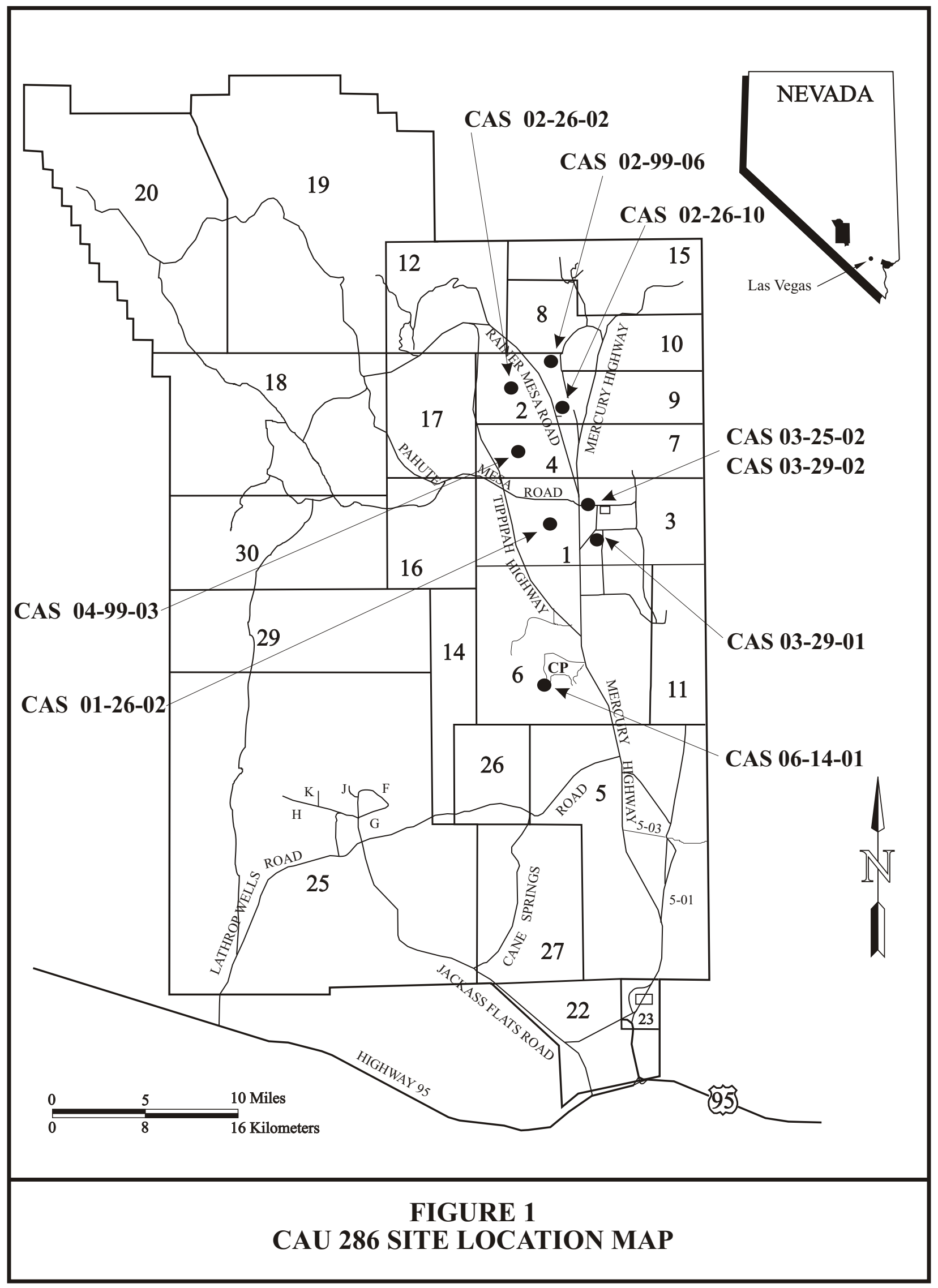




\subsection{CLOSURE ACTIVITIES}

This section details the specific closure activities completed for CAU 286: Lead/Chemical/Spill Sites and Material Dumps.

\subsection{DESCRIPTION OF Closure ACTIVITIES}

\subsubsection{Preplanning and Site Preparation}

Planning documents prepared prior to the beginning of closure activities include the following:

- $\quad$ Sectored Clean-up Work Plan For Housekeeping Category Waste Sites (U.S. Department of Energy, National Nuclear Security Administration Nevada Site Office [NNSA/NSO], 2003).

- $\quad$ Generic Field Management Plan for Housekeeping Category Waste Sites (NNSA/NSO, 2005).

- $\quad$ Site-Specific Health and Safety Plan for Corrective Action Units 167, 210, 286, 390, and 395 Housekeeping Sites, Nevada Test Site, Nevada, Revision 1, (Bechtel Nevada [BN], 2005).

- BN Solid Waste Operations Work Packages.

- $\quad$ NNSA/NSO Real Estate/Operation Permit.

\subsection{Waste Classification Activities}

None of the sites required waste classification activities.

\subsection{Site Closure ACtivities}

Appendix B includes the "Housekeeping Site Closure Verification Forms," including site information and before-and-after site photographs.

\subsubsection{CAS 01-26-02: Lead Sheets; Lead Lined Pit}

On June 1, 2005, the pit was excavated and removed. The pit consis ted of a 4-foot (ft) diameter steel casing that extended to a depth of $6 \mathrm{ft}$ below grade. During the investigation, the pit wall was noted to be constructed of steel, and no lead lining was present. The pit was filled with $4 \mathrm{ft}$ of trash that included plastic, scrap metal, paper, and wood scrap covered with $2 \mathrm{ft}$ of soil. The trash was screened for radiological constituents and was disposed of as sanitary waste at the U10c Landfill. A total of 15 cubic yards $\left(\mathrm{yd}^{3}\right)$ of material, including the steel pit wall, trash, and soil, were disposed of as construction debris. No further action is required at this site.

\subsubsection{CAS 02-26-02: Lead Pipes/Radiation (RAD) Area}

The lead pipes were no longer located at the site. However, their former location was determined by examining a photograph taken in 1990. A total of three verification samples (022602-1, 022602-3, and 022602-3) were collected from the former location of the pipes on November 7, 2003. The samples were submitted for laboratory analysis for total lead. Laboratory results showed lead concentrations less than the U.S. Environmental Protection 
Agency (EPA) Region 9 Preliminary Remediation Goal (PRG) for lead in soil at industrial sites (EPA, 2002). Therefore, no further action is required at this site.

\subsubsection{CAS 02-26-10: Lead Shot}

On June 1, 2005 approximately 2 cubic feet $\left(\mathrm{ft}^{3}\right)$ of lead shot and associated soil were removed from this CAS and staged for later disposal as hazardous waste. One verification sample (022610-V1) was collected from the bottom of the excavation and submitted for laboratory analysis of total lead. Laboratory results showed a lead concentration less than the PRG (EPA, 2002). Therefore, no further action is required at this site.

\subsubsection{CAS 02-99-06: Material Dump}

The site consisted of three small piles of concrete totaling approximately $5 \mathrm{yd}^{3}$ of material. The material was removed mechanically from the ground surface and transported for disposal at the Area 9 U10c Landfill. No further action is required at this site.

\subsubsection{CAS 03-25-02: Oil Spills}

This CAS consisted of approximately $2 \mathrm{ft}^{3}$ of dried asphalt that was located on a concrete pad. The material was removed and transported to the Area 9 U10c Landfill for disposal. No further action is required at this site.

\subsubsection{CAS 03-29-01: Methyl Alcohol Bottle}

The bottle that was identified in the 1990 Site Inventory was no longer present in the shed on the rear of the Huron King Test Vehicle. No further action is required at this site.

\subsubsection{CAS 03-29-02: Acid Box; Chemicals}

The box that was identified in the 1990 Site Inventory was previously removed from the site. The building in which it was located has also since been demolished. No evidence of staining was noted on the concrete building pad. No further action is required at this site.

\subsubsection{CAS 04-99-03: Oil (Quart)}

The site consists of an oil can that was reportedly located at the bottom of a bunker entrance shaft. The shaft was approximately $20-\mathrm{ft}$ deep. Due to safety concerns, the bunker shaft was not entered and the shaft lid was closed. No further action is required at this site.

\subsubsection{CAS 06-14-01: Radiation Counting Shield (Lead)}

This counting shield identified in the 1990 Site Inventory was no longer on site. The buildings in the area had also since been demolished. No further action is required at this site. 


\subsection{WASTE DISPOSITION}

Waste generated during the closure of CAU 286 was disposed as follows:

- CAS 01-26-02: Approximately $15 \mathrm{yd}^{3}$ of material was transported for disposal at U10c Landfill.

- CAS 02-26-02: No waste generated.

- CAS 02-26-10: Approximately $2 \mathrm{ft}^{3}$ of lead shot and associated soil were disposed of offsite as hazardous waste.

- CAS 02-99-06: Approximately $5 \mathrm{yd}^{3}$ of concrete was transported for disposal at U10c Landfill.

- CAS 03-25-02: Approximately $2 \mathrm{ft}^{3}$ of asphalt was transported for disposal at U10c Landfill.

- CAS 03-29-01: No waste generated.

- CAS 03-29-02: No waste generated.

- CAS 04-99-03: No waste generated.

- CAS 06-14-01: No waste generated. 
Closure Report - CAU 286

Section: Waste Disposition

Revision: 0

Date: August 2005

THIS PAGE INTENTIONALLY LEFT BLANK 


\subsection{CLOSURE VERIFICATION}

Closure activities at two CASs (CAS 02-26-02 and CAS 02-26-10) included collecting soil verification samples. Copies of the analytical results for the verification samples are included in Appendix A. Copies of the "Sectored Housekeeping Site Closure Verification Forms" for the CASs are included in Appendix B.

Samples were collected from a total of four locations after the removal of waste or from the surface in the location of waste that was previously removed. The samples were collected with clean disposable plastic scoops, placed in labeled sample containers, and secured with custody seals. The sample containers were placed on ice in a cooler and maintained at less than 4 degrees Celsius. The samples were then transported under chain of custody to the BN Sample Management Group in Mercury, Nevada, and shipped to an offsite laboratory for analysis.

At CAS 02-26-02, a total of three verification samples (022602-1, 022602-3, and 022602-3) were collected on November 7, 2003, from the former location of lead pipes. At CAS 02-26-10, one verification sample (022610-V1) was collected from the bottom of the shallow excavation.

All four samples were submitted for laboratory analysis of total lead. Laboratory results showed lead concentrations less than the EPA Region 9 PRG for soil at industrial sites (EPA, 2002). The analytical results are summarized in Table 1. Copies of the analytical reports are included in Appendix A.

\section{Table 1. Summary Of ANAlytical Results for Verification SAMPleS}

\begin{tabular}{||c|c|c|c||}
\hline $\begin{array}{c}\text { SAMPLE } \\
\text { IDENTIFICATION }\end{array}$ & $\begin{array}{c}\text { SAMPLE } \\
\text { DATE }\end{array}$ & $\begin{array}{c}\text { SAMPLE DEPTH } \\
\text { (feet) }\end{array}$ & $\begin{array}{c}\text { TOTAL LEAD }^{\text {Tot }} \\
\text { (mg/kg) }\end{array}$ \\
\hline \hline PRG for Lead & & & 750 \\
\hline \hline $022602-1$ & November 7, 2003 & Surface & $<2.5$ \\
\hline $022602-2$ & November 7, 2003 & Surface & 17 \\
\hline $022602-3$ & November 7, 2003 & Surface & 300 \\
\hline $022610-\mathrm{V} 1$ & June 1, 2005 & 1 & 91.0 \\
\hline
\end{tabular}

a Total Lead samples analyzed by U.S. Environmental Protection Agency (EPA) SW-846 Method 6010B (EPA, 1996). See analytical reports in Appendix A for laboratory detection limits.

* $\mathrm{mg} / \mathrm{kg}=$ milligrams per kilogram 
THIS PAGE INTENTIONALLY LEFT BLANK 


\subsection{SUMMARY AND RECOMMENDATIONS}

\subsection{SUMMARY}

The following closure activities were completed at the CASs in CAU 286:

- CAS 01-26-02, Lead Sheets; Lead Lined Pit: Clean-closed by excavation and disposal of the steel pit wall and associated trash at U10c Landfill. No further action necessary.

- CAS 02-26-02, Lead Pipes/RAD Area: Clean-closed by collecting verification samples in the former locations of the pipes that were previously removed. No further action necessary.

- CAS 02-26-10, Lead Shot: Clean-closed by removal of $2 \mathrm{ft}^{3}$ of lead shot and associated soil for offsite disposal as hazardous waste. No further action necessary.

- CAS 02-99-06, Material Dump: Clean-closed by disposal of approximately $5 \mathrm{yd}^{3}$ of concrete at U10c Landfill. No further action necessary.

- CAS 03-25-02, Oil Spills: Clean-closed by disposal of $2 \mathrm{ft}^{3}$ of broken-up asphalt at U10c Landfill. No further action necessary.

- CAS 03-29-01, Methyl Alcohol Bottle: No action taken, because debris was previously removed.

- CAS 03-29-02, Acid Box; Chemicals: No action taken, because debris was previously removed.

- $\quad$ CAS 04-99-03, Oil (Quart): No action taken due to access restrictions to waste and personnel safety concerns. Bunker shaft lid has been closed for safety reasons.

- CAS 06-14-01, Radiation Counting Shield (Lead): No action taken, because debris was previously removed.

\subsection{RECOMMENDATIONS}

Because closure activities for CAU 286 have been completed following the Nevada Division of Environmental Protection (NDEP)-approved Sectored Clean-up Work Plan for Housekeeping Category Waste Sites (NNSA/NSO, 2003) as documented in this report, NNSA/NSO requests the following:

1. NDEP provide a "Notice of Completion" to the NNSA/NSO for the closure of CAU 286.

2. CAU 286 be transferred from Appendix III to Appendix IV of the FFACO Closed Corrective Action Units (FFACO, 1996). 
THIS PAGE INTENTIONALLY LEFT BLANK 


\subsection{REFERENCES}

BN, see Bechtel Nevada.

Bechtel Nevada. 2005. Site-Specific Health and Safety Plan for Corrective Action Sites 167, 210, 286, 390, and 395, Nevada Test Site, Nevada, Rev. 1. Las Vegas, NV.

EPA, see U.S. Environmental Protection Agency.

FFACO, see Federal Facility Agreement and Consent Order.

Federal Facility Agreement and Consent Order. 1996 (as amended). Agreed to by the State of Nevada, U.S. Department of Energy, and U.S. Department of Defense.

NDEP, see Nevada Division of Environmental Protection.

NNSA/NSO, see U.S. Department of Energy, National Nuclear Security Administration Nevada Site Office.

U.S. Department of Energy, National Nuclear Security Administration Nevada Site Office. 2005. Generic Field Management Plan for Housekeeping Category Waste Sites, Revision 2, Las Vegas, NV.

U.S. Department of Energy, National Nuclear Security Administration Nevada Site Office. 2003. Sectored Clean- up Work Plan for Ho usekeeping Category Waste Sites, DOE/NV--579-REV-3. Las Vegas, NV.

U.S. Environmental Protection Agency. 1996. Test Methods for Evaluating Solid Waste, Physical/Chemical Methods, EPA Publication SW-846, Third Edition. Washington, D.C.

U.S. Environmental Protection Agency. 2002. Region IX Preliminary Remediation Goals (PRGs), San Francisco, CA. 
Closure Report - CAU 286

Section: References

Revision: 0

Date: August 2005

THIS PAGE INTENTIONALLY LEFT BLANK 
Closure Report - CAU 286

Section: Appendix A

Revision: 0

Date: August 2005

\section{APPENDIX A}

\section{SAMPLE ANALYTICAL RESULTS}


Closure Report - CAU 286

Section: Appendix A

Revision: 0

Date: August 2005

THIS PAGE INTENTIONALLY LEFT BLANK 


\section{ApPendiX A. Sample Analytical Results By Sample Delivery Group}

Analytical results for the samples collected at the indicated Corrective Action Site (CAS) for Corrective Action Unit 286 are presented in this Appendix. The analytical results are grouped by Sample Delivery Group, which are arranged in numerical order in this Appendix. Analytical results for the specific CAS can be found by consulting the indicated Sample Delivery Group.

\begin{tabular}{ccc} 
CAS & Sample Delivery Group & Analysis \\
\hline $02-26-02$ & V2128 & Total Lead \\
$02-26-10$ & V2480 & Total Lead
\end{tabular}


Closure Report - CAU 286

Section: Appendix A

Revision: 0

Date: August 2005

THIS PAGE INTENTIONALLY LEFT BLANK 
Closure Report - CAU 286

Section: Appendix A

Revision: 0

Date: August 2005

\section{SAMPle DELIVERY GROUP}

V2128 
Closure Report - CAU 286

Section: Appendix A

Revision: 0

Date: August 2005

THIS PAGE INTENTIONALLY LEFT BLANK 
NEL Laboratories, Las Vegas

CLIENT: Bechtel Nevada

Lab Order: $\quad$ L0311189

Project: V2128

Lab ID: $\quad$ L0311189-001
Date: $19-\mathrm{Nov}-03$

Client Sample ID: 022602-1

Collection Date: 11/7/03 2:30:00 PM

Matrix: SOLID

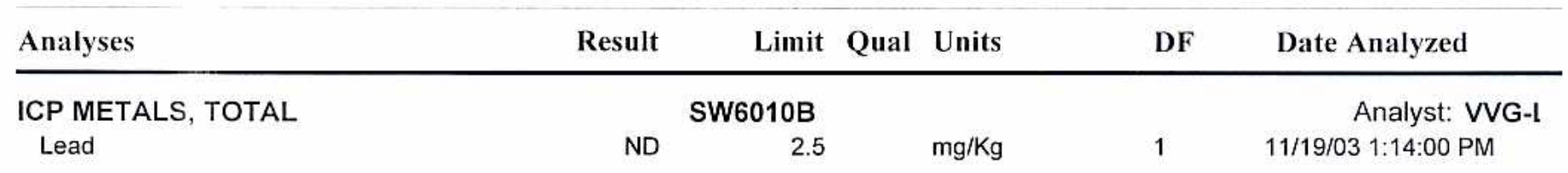

Qualifiers: ND - Not Detected at the Reporting Limit

$\mathrm{J}$ - Analyte detected below quanititation limits

B - Analyte detected in the associated Method Blank

* - Value exceeds Maximum Contaminant Level
S - Spike Recovery outside accepted recovery limits

R - RPD outside accepted recovery limits

$\mathrm{E}$ - Value above quantitation range

Page 1 of 3 
NEL Laboratories, Las Vegas

CLIENT: Bechtel Nevada

Lab Order: $\quad$ L0311189

Project: V2128

Lab ID: $\quad$ L0311189-002
Date: $19-\mathrm{Nov}-03$

\begin{tabular}{|c|c|c|c|c|c|c|}
\hline Analyses & Result & Limit & Qual & Units & DF & Date Analyzed \\
\hline ICP METALS, TOTAL & & 010B & & & & Analyst: VVG-I \\
\hline Lead & 17 & 2.5 & & $\mathrm{mg} / \mathrm{Kg}$ & 1 & 11/19/03 1:27:00 PM \\
\hline
\end{tabular}

Qualifiers: ND - Not Detected at the Reporting Limit

$\mathrm{J}$ - Analyte detected below quanititation limits

B - Analyte detected in the associated Method Blank

* - Value exceeds Maximum Contaminant Level
Client Sample ID: 022602-2

Collection Date: 11/7/03 2:40:00 PM

Matrix: SOLID 
NEL Laboratories, Las Vegas

\section{CLIENT: Bechtel Nevada}

Lab Order: $\quad$ L0311189

Project: V2128

Lab ID:

L0311189-003
Date: $19-\mathrm{Nov}-03$

Client Sample ID: 022602-3

Collection Date: 11/7/03 2:50:00 PM

Matrix: SOLID

\begin{tabular}{|c|c|c|c|c|c|c|}
\hline Analyses & Result & Limit & Qual & Units & DF & Date Analyzed \\
\hline ICP METALS, TOTAL & & $6010 \mathrm{~B}$ & & & & Analyst: V \\
\hline
\end{tabular}

Qualifiers: ND - Not Detected at the Reporting Limit

$\mathrm{J}$ - Analyte detected below quanititation limits

B - Analyte detected in the associated Method Blank

* - Value exceeds Maximum Contaminant Level
S - Spike Recovery outside accepted recovery limits

R - RPD outside accepted recovery limits

$\mathrm{E}$ - Value above quantitation range 
Closure Report - CAU 286

Section: Appendix A

Revision: 0

Date: August 2005

\section{SAMPLE DELIVERY GROUP}

V2480 
Closure Report - CAU 286

Section: Appendix A

Revision: 0

Date: August 2005

THIS PAGE INTENTIONALLY LEFT BLANK 


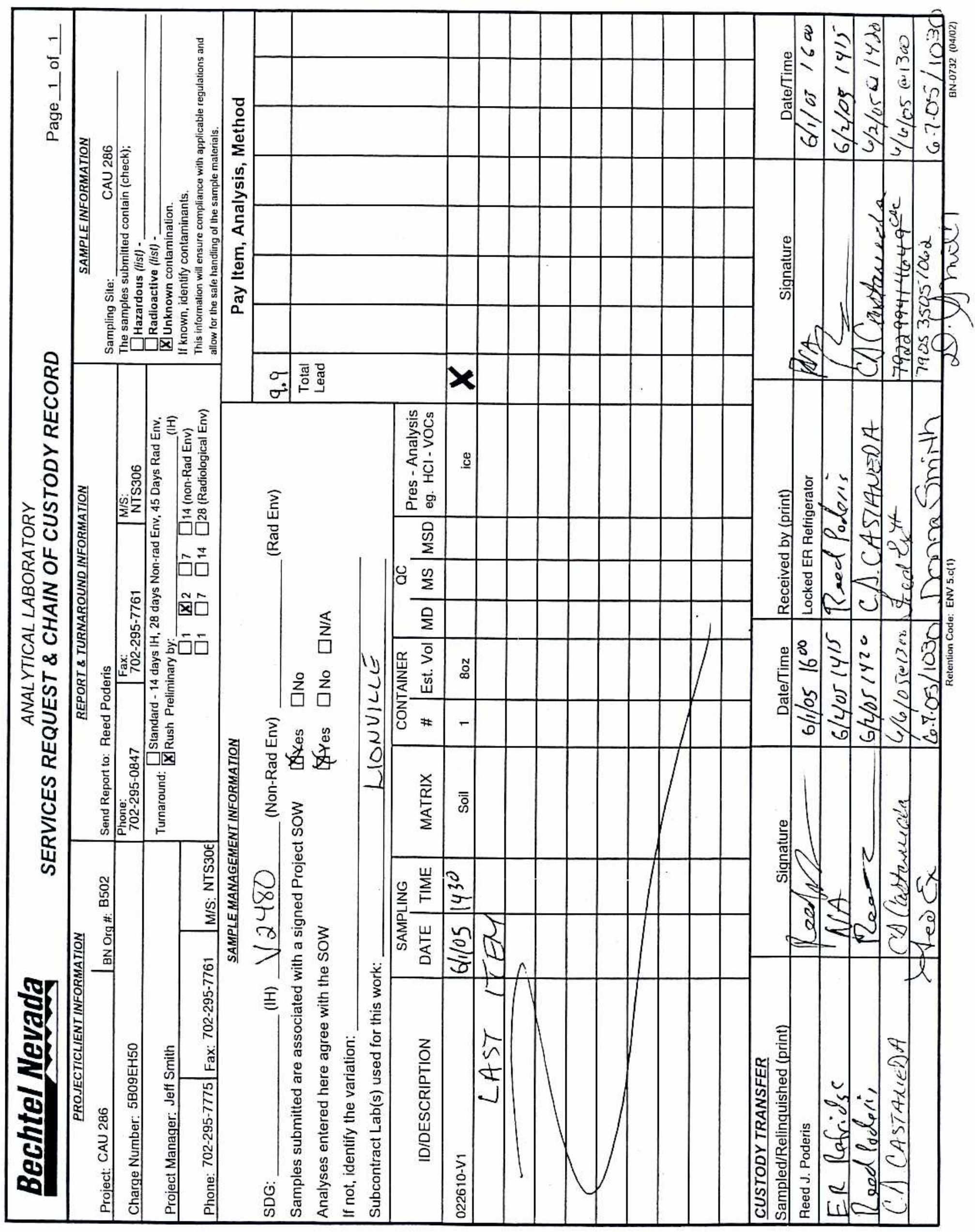


1

INORGANIC ANALYSES DATA SHEET
Lab Name: LIONVILLE_LABORATORY

Lab Code: LVLI

Matrix (soil/water): SolL_

Level (low/med): \% Solids:
Contract: 60052

$$
\text { LOW }
$$

EPA SAMPLE NO.

022610

Lab Sample ID: 0506L683-001

Date Received: 06/07/05

Concentration Units (ug/L or $\mathrm{mg} / \mathrm{kg}$ dry weight): MG/KG

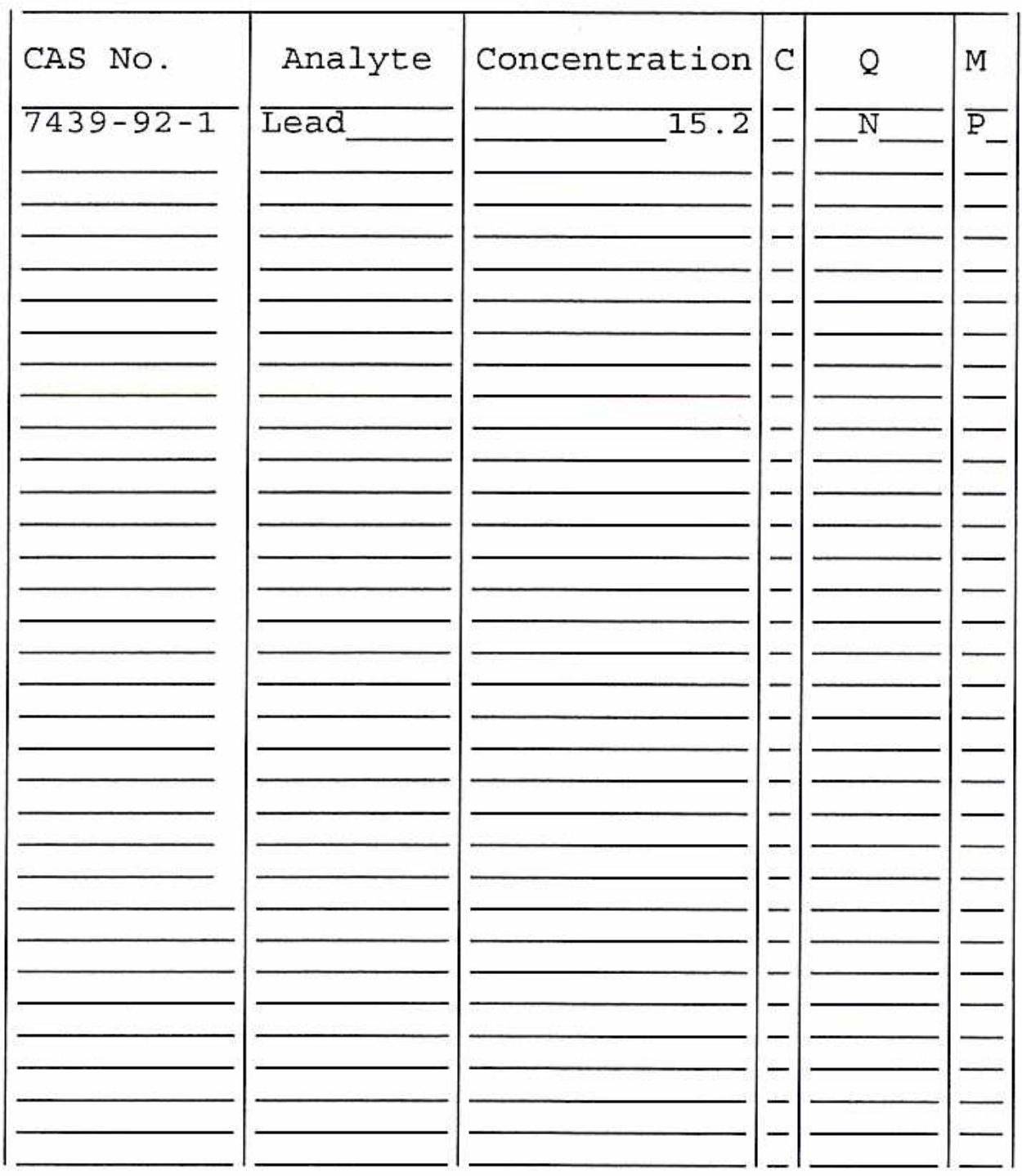

Color Before: Color After:
Clarity Before: Clarity After:
Texture: Artifacts :

\section{Comments :}

$022610-\mathrm{V} 1$ 


\section{APPENDIX B}

\section{SECTORED HOUSEKEEPING SITE CLOSURE VERIFICATION FORMS}


Closure Report - CAU 286

Section: Appendix B

Revision: 0

Date: August 2005

\section{THIS PAGE INTENTIONALLY LEFT BLANK}




\section{Sectored Housekeeping Site Closure Verification Form}

Closure Verification Date: 06-01-2005

CAU Number: 286

CAS Number: 01-26-02

CAS Description: Lead Sheets; Lead Lined Pit

Sector Designation: NTS Sector E

Housekeeping Site Gene ral Location: Apple II Brick House Area

Elevation: 4,080 feet

Northing: 4,100,060 m (UTM Zone 11) Easting: 582,654 m (UTM Zone 11)

Latitude: 37.04312

Longitude: -116.07054

Coordinate/Elevation Data Obtained from: North American Datum, 1983.

Site Access Route: Mercury Highway north to Pahute Mesa Road. Turn left (west) onto Pahute Mesa Road and travel 1.5 miles. At this point, turn south and proceed 0.5 mile to a dirt road on the left (east). Turn left and proceed 0.5 mile to a brick structure. The site is approximately 0.08 mile west of the brick structure.

\begin{tabular}{|l|l|}
\hline \multicolumn{1}{|c|}{ Waste Item(s) Originally at Site } & \multicolumn{1}{c|}{ Apparent Waste Type* } \\
\hline Instrument pit listed as lead-lined. & Sanitary. Pit was not lead-lined. \\
\hline * Ordinary, Scrap Metal, Asbestos, PCB, Salvageable, Hazardous, Radioactive, Mixed, Unknown, Other \\
\hline
\end{tabular}




\section{Sectored Housekeeping Site Closure Verification Form}

Closure Verification Date: 11/07/2003

CAU Number: 286

CAS Number: 02-26-02

CAS Description: Lead Pipes/RAD Area

Sector Designation: NTS Sector F

Housekeeping Site General Location: RSM 2 N 8

Elevation: 4,480 feet

Northing: 4,111,540 m (UTM Zone 11) Easting: 578,338 m (UTM Zone 11)

Latitude: $37.13795 \quad$ Longitude: -116.11798

Coordinate/Elevation Data Obtained from: North American Datum, 1983.

Site Access Route: Mercury Highway north to Rainier Mesa Road. Turn left (northwest) on Rainier Mesa Road and proceed to 2-04 Road. Turn left (west) on 2-04 Road and continue approximately 2.1 miles. The site is located on the right side of the road, approximately $7 \mathrm{ft}$ north of a radiation fence and approximately $100 \mathrm{ft}$ east of RSM 2 N 8.

\begin{tabular}{|l|c|}
\hline \multicolumn{1}{|c|}{ Waste Item(s) Originally at Site } & \multicolumn{1}{c|}{ Apparent Waste Type* } \\
\hline Lead Pipes & None. Pipes previously removed. \\
\hline * Ordinary, Scrap Metal, Asbestos, PCB, Salvageable, Hazardous, Radioactive, Mixed, Unknown, Other \\
\hline
\end{tabular}




\section{Sectored Housekeeping Site Closure Verification Form}

Closure Verification Date: 06/01/2005

CAU Number: 286

CAS Number: 02-26-10

CAS Description: Lead Shot

Sector Designation: NTS Sector F

Housekeeping Site General Location: U2gb

Elevation: 4,220 feet

Northing: 4,109,220 m (UTM Zone 11) Easting: 583,347 m (UTM Zone 11)

Latitude: 37.12562

Longitude: -116.06173

Coordinate/Elevation Data Obtained from: North American Datum, 1983.

Site Access Route: Mercury Highway north to 9-01 Road. Turn onto 9-01 Road and proceed east to Circle Road. Turn right (south) on Circle Road and travel 0.65 mile to 2D Road. Turn right (west) on 2D Road and proceed 0.2 mile to a fork in the road. Take the left fork and proceed around the U-2bg Potential Crater. The marker and lead shot lie on the northwest side of the crater fenceline.

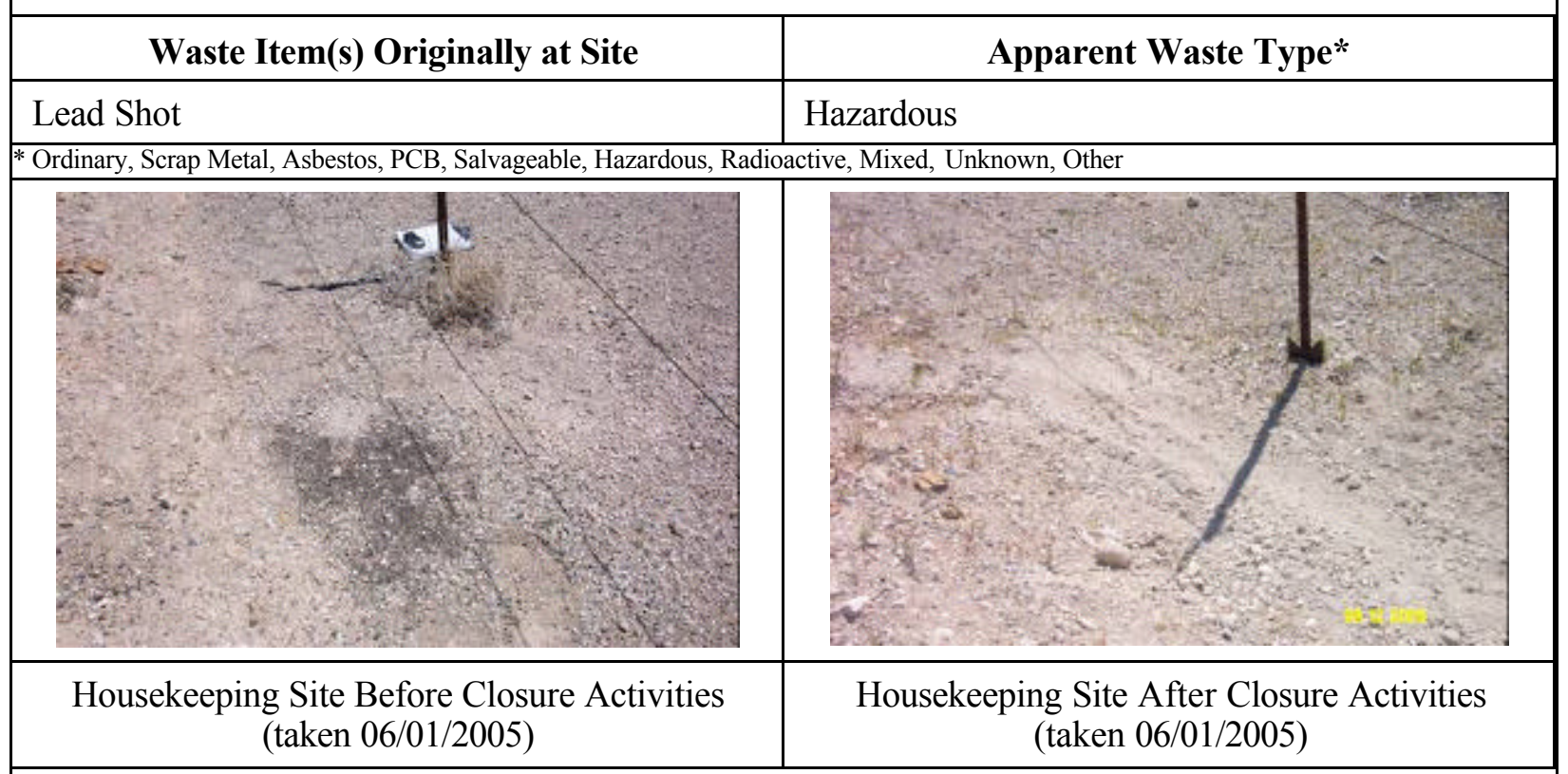

Current Site Description/Observations: Approximately 2 cubic feet of lead shot and associated soil were disposed of as hazardous waste. Verification sample confirmed no lead remained on site above preliminary remediation goals closure results. No waste remains on site.

\section{No Further Action Required at Housekeeping Site}

Reed J. Poderis, CEM SIGNATURE APPROVED 8/10/05 Corrective Action Coordinator/Designee Signature Date 


\section{Sectored Housekeeping Site Closure Verification Form}

Closure Verification Date: 06/02/2005

CAU Number: 286

CAS Number: 02-99-06

CAS Description: Material Dump

Sector Designation: NTS Sector F

Housekeeping Site General Location: U-2bp PS \#2

Elevation: 4,320 feet

Northing: 4,113,155 m (UTM Zone 11) Easting: 583,084 m (UTM Zone 11)

Latitude: 37.16111

Longitude: -116.06425

Coordinate/Elevation Data Obtained from: North American Datum, 1983.

Site Access Route: Mercury Highway north to Rainier Mesa Road. Turn left (west) on Rainier Mesa Road and proceed to 2-07 Road. Turn right (east) on 2-07 Road and continue 1.2 miles to a faint dirt road on the right (south). Turn right on the dirt road and proceed 0.3 miles. The site is on the left (east) side of the dirt road. The site is located at U-2bj PS \#1A, as stated in the original Reynolds Electrical \& Engineering Co., Inc., Inventory.

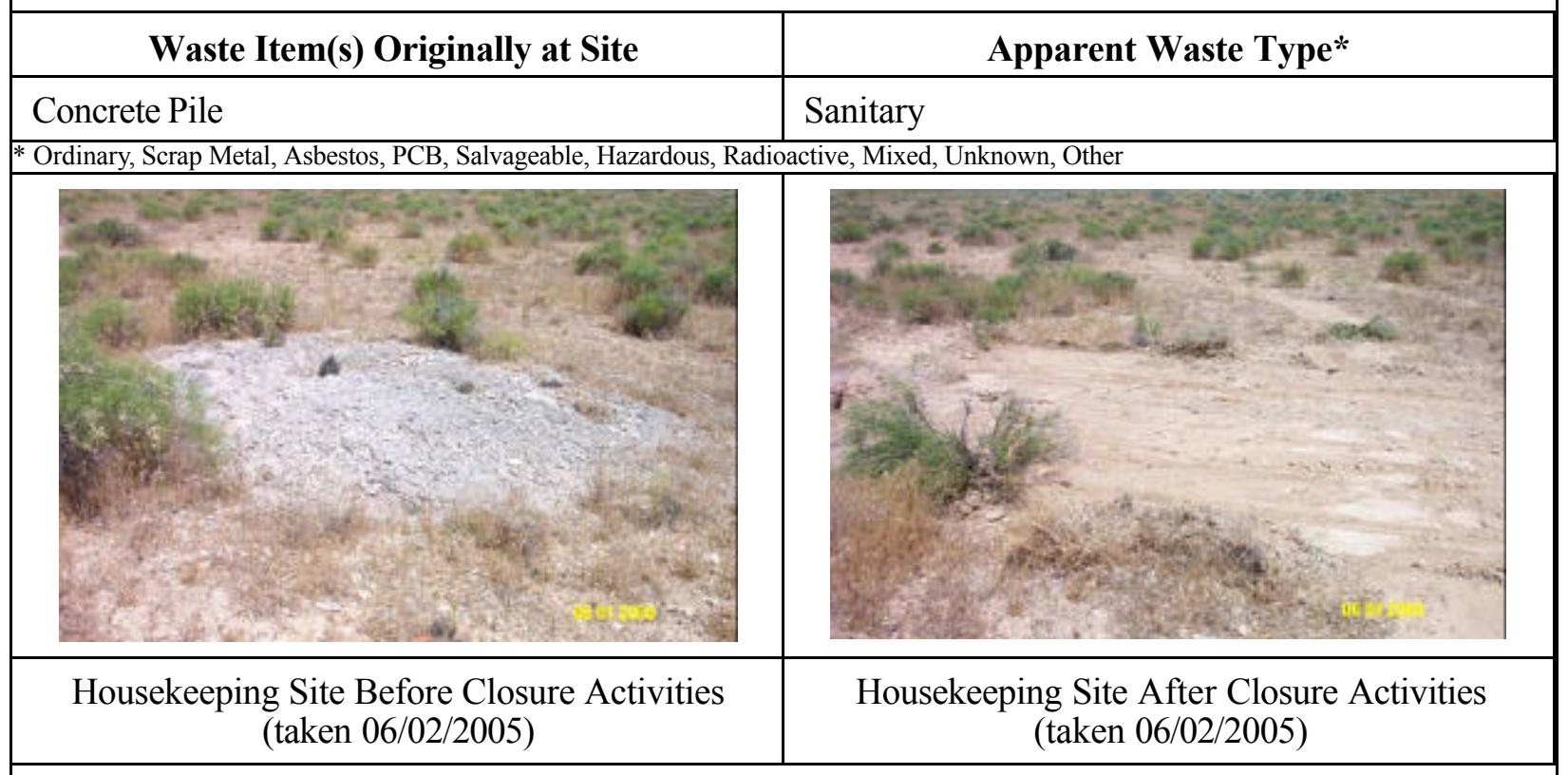

Current Site Description/Observations: Approximately 5 cubic yards of concrete were disposed of as sanitary waste at the U10c Landfill. No waste remains onsite.

\section{No Further Action Required at Housekeeping Site}

Reed J. Poderis, CEM SIGNATURE APPROVED 8/10/05 Corrective Action Coordinator/Designee

Signature Date




\section{Sectored Housekeeping Site Closure Verification Form}

Closure Verification Date: 06/02/2005

CAU Number: 286

CAS Number: 03-25-02

CAS Description: Oil Spills

Sector Designation: NTS Sector E

Housekeeping Site General Location: Area 3 Subdock

Elevation: 4,050 feet

Northing: 4,100,906 m (UTM Zone 11) Easting: 584,249 m (UTM Zone 11)

Latitude: $37.16111 \quad$ Longitude: -116.06425

Coordinate/Elevation Data Obtained from: North American Datum, 1983.

Site Access Route: Mercury Highway north approximately 0.15 mile past 3-03 Road. The debris pile is located just east of the telephone poles.

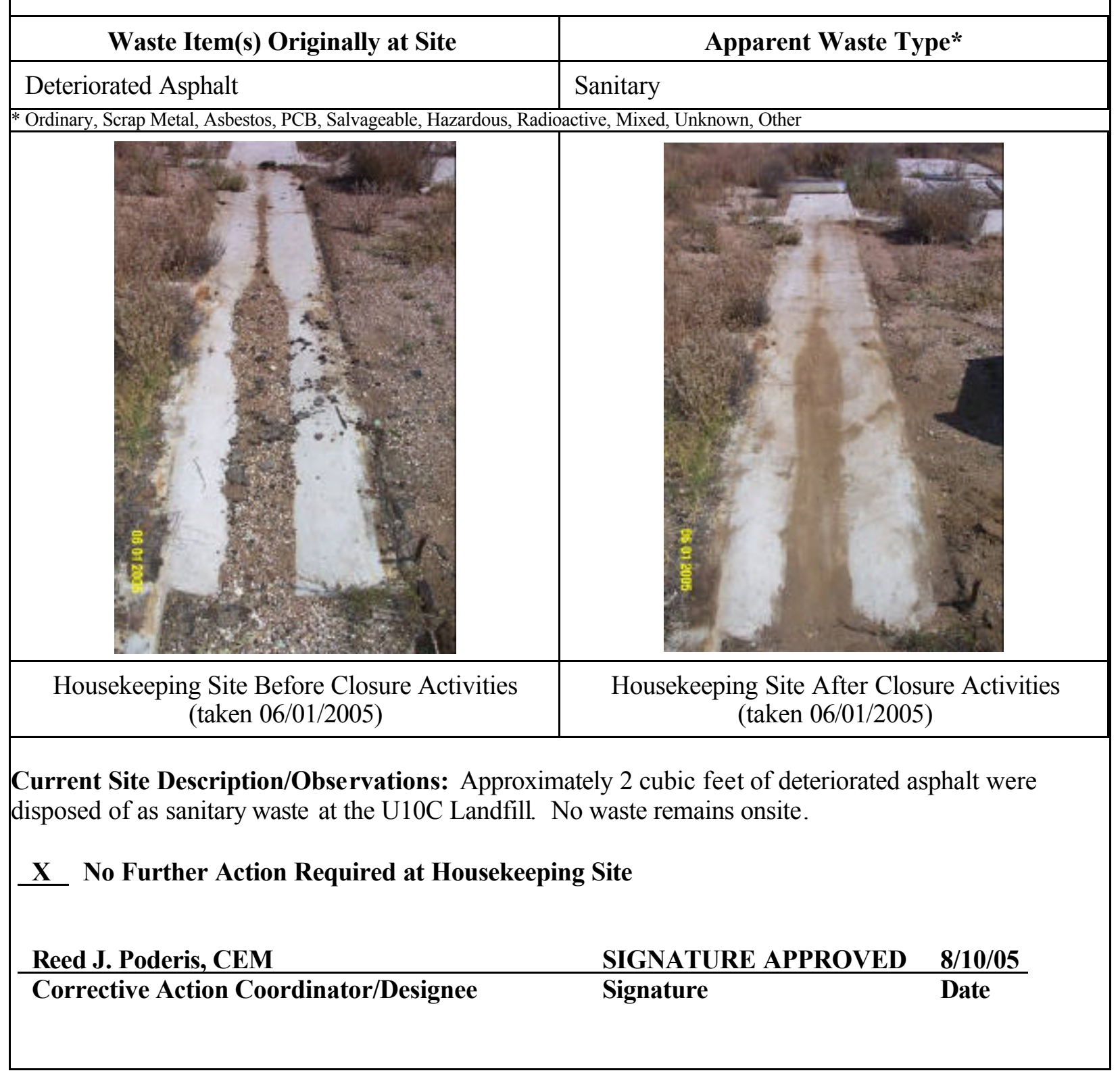




\section{Sectored Housekeeping Site Closure Verification Form}

Closure Verification Date: 07/23/2003

CAU Number: 286

CAS Number: 03-29-01

CAS Description: Methyl Alcohol Bottle

Sector Designation: NTS Sector E

Housekeeping Site General Location: Huron King Test Vehicle

Elevation: 3,980 feet

Northing: 4,098,083 m (UTM Zone 11) Easting: 586,395 m (UTM Zone 11)

Latitude: 37.02497

Longitude: - 116.0287

Coordinate/Elevation Data Obtained from: North American Datum, 1983.

Site Access Route: Mercury Highway north to Angle Road. Turn right (northeast) on Angle Road and proceed 1.3 miles to 3-07 Road. Turn right (east) on 3-07 Road and proceed approximately 0.5 mile to 3-12 Road. Turn right (south) on 3-12 Road 3B2, then immediately right again (west) on a dirt/gravel track and proceed to the Huron King Satellite Vehicle. The Satellite Vehicle is a large, white object in the middle of the flat.

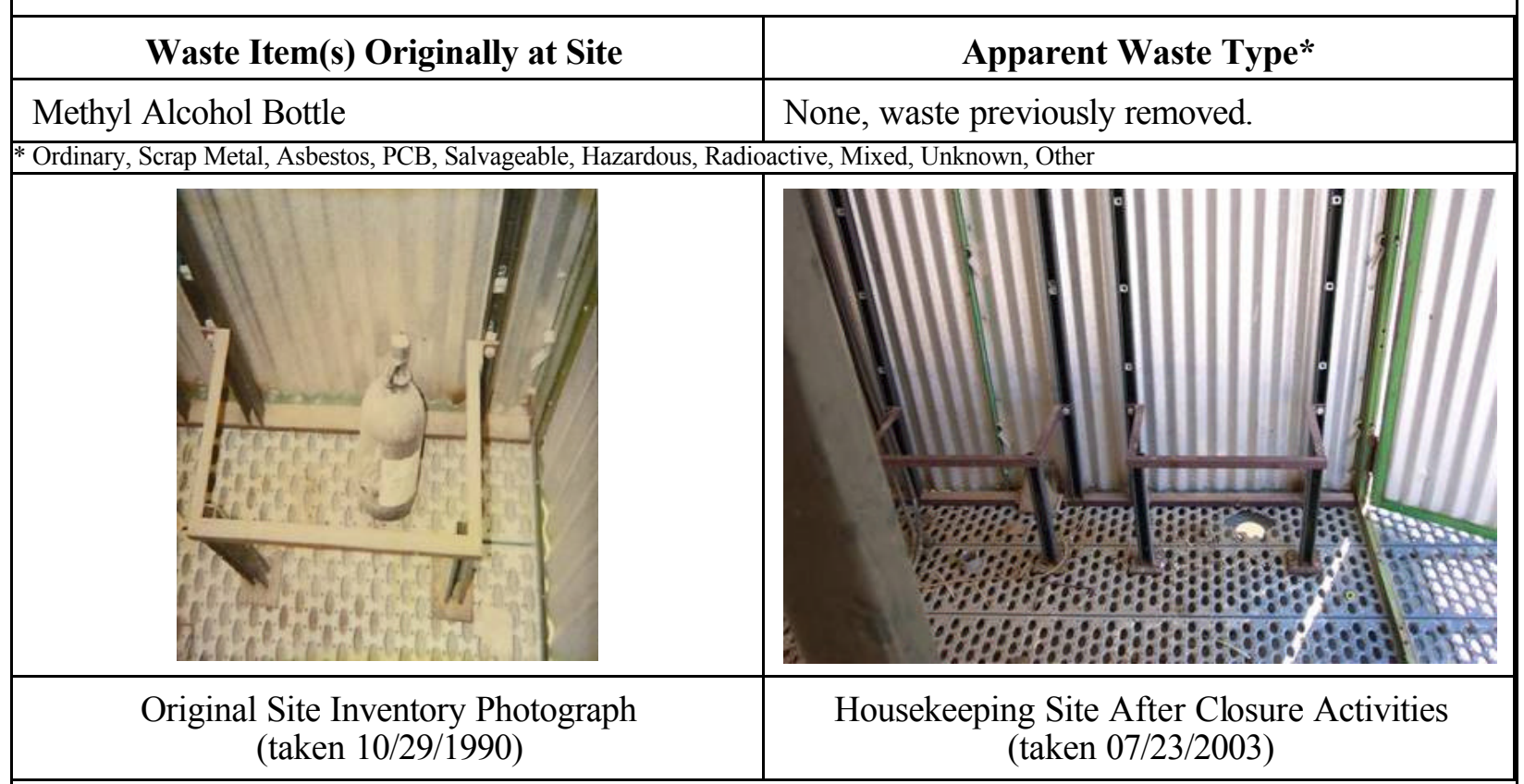

Current Site Description/Observations: Waste was previously removed. No waste remains onsite.

$\underline{X}$ No Further Action Required at Housekeeping Site

Reed J. Poderis, CEM

SIGNATURE APPROVED 8/10/05

Corrective Action Coordinator/Designee

Signature

Date 


\section{Sectored Housekeeping Site Closure Verification Form}

Closure Verification Date: 07/23/2003

CAU Number: 286

CAS Number: 03-29-02

CAS Description: Acid Box; Chemicals

Sector Designation: NTS Sector E

Housekeeping Site General Location: Core/ETS Building

Elevation: 4,030 feet

Northing: 4,100,747 m (UTM Zone 11) Easting: 584,851 m (UTM Zone 11)

Latitude: 37.04912

Longitude: -116.04576

Coordinate/Elevation Data Obtained from: North American Datum, 1983.

Site Access Route: Mercury Highway north to 3-03 Road. Turn right (east) on 3-03 Road and proceed approximately 0.4 mile to the old Core Building on the left (north) side of the road.

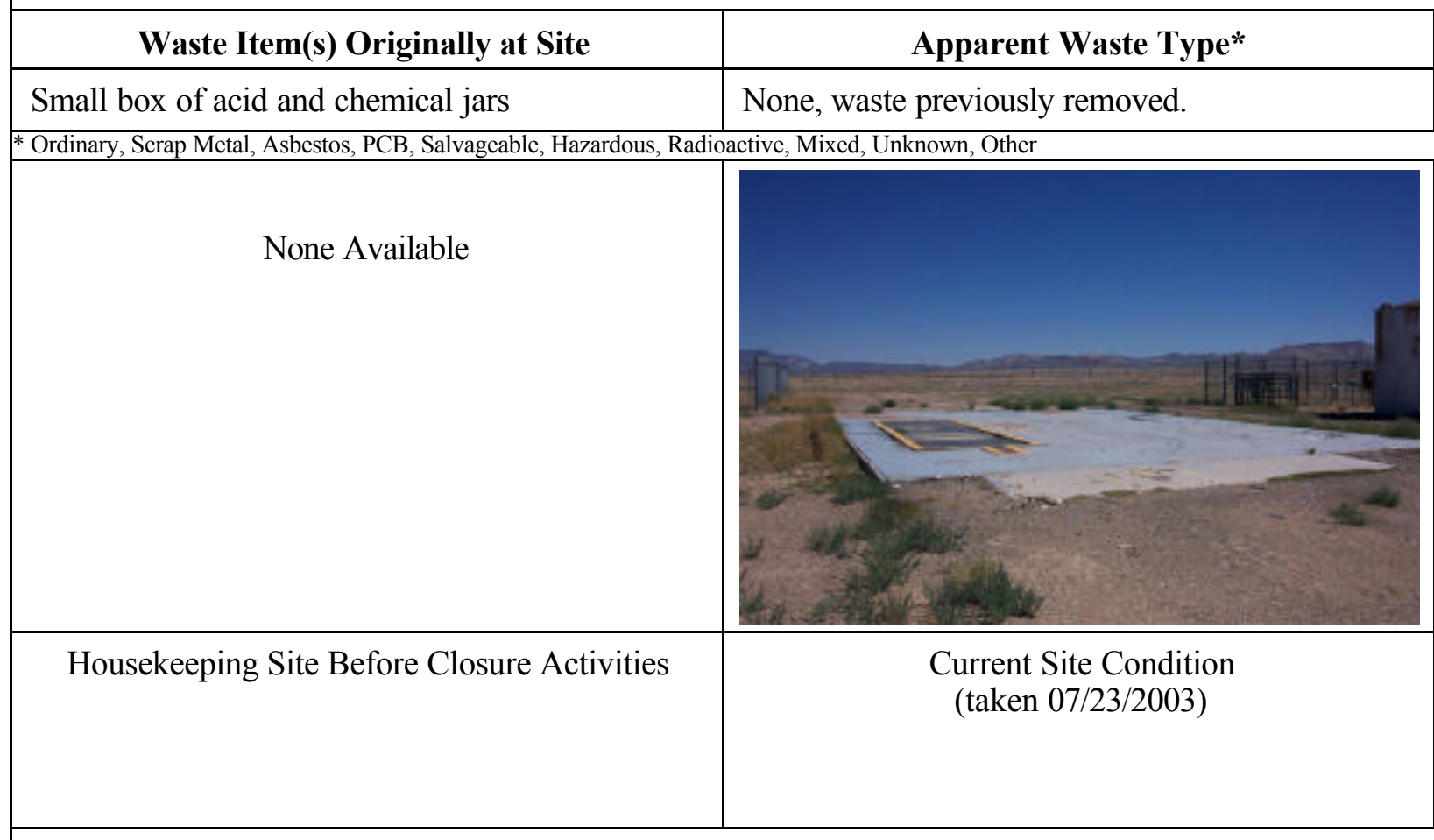

Current Site Description/Observations: Waste was previously removed. No waste remains onsite.

X No Further Action Required at Housekeeping Site

Reed J. Poderis, CEM

SIGNATURE APPROVED $\quad 8 / 10 / 05$

Corrective Action Coordinator/Designee

Signature

Date 


\section{Sectored Housekeeping Site Closure Verification Form}

Closure Verification Date: 07/23/2003

CAU Number: 286

CAS Number: 04-99-03

CAS Description: Oil (Quart)

Sector Designation: NTS Sector E

Housekeeping Site General Location: Bunker 4380

Elevation: 4,340 feet

Northing: 4,105,792 m (UTM Zone 11) Easting: 579,206 m (UTM Zone 11)

Latitude: 37.09508

Longitude: - 116.10871

Coordinate/Elevation Data Obtained from: North American Datum, 1983.

Site Access Route: Mercury Highway north to Rainier Mesa Road. Turn left (northwest) on Rainier Mesa Road and proceed to 4-04 Road. Turn left (west) and proceed 2.3 miles to Bunker 4-380, on the north side of the road.

\begin{tabular}{|l|l|c|}
\hline \multicolumn{1}{|c|}{ Waste Item(s) Originally at Site } & Apparent Waste Type* \\
\hline Oil Quart Can & None, access restricted due to safety concerns. \\
\hline * Ordinary, Scrap Metal, Asbestos, PCB, Salvageable, Hazardous, Radioactive, Mixed, Unknown, Other \\
\hline
\end{tabular}




\section{Sectored Housekeeping Site Closure Verification Form}

Closure Verification Date: 07/23/2003

CAU Number: 286

CAS Number: 06-14-01

CAS Description: Radiation Counting Shield (Lead)

Sector Designation: NTS Sector C

Housekeeping Site General Location: CP-400

Elevation: 4,200 feet

Northing: 4,087,761 m (UTM Zone 11) Easting: 584,035 m (UTM Zone 11)

Latitude: 36.93215

Longitude: -116.05638

Coordinate/Elevation Data Obtained from: North American Datum, 1983.

Site Access Route: Mercury Highway north past the Area 6 Control Point to 6-01 Road. Turn left (west) on 6-01 Road and continue 0.5 mile (road becomes dirt) to a dirt road. Take a sharp left (east) on the dirt road and travel east and then south up the hill to Building CP-55. The site is located north of the building.

\begin{tabular}{|c|c|}
\hline \multicolumn{1}{|c|}{ Waste Item(s) Originally at Site } & Apparent Waste Type* \\
\hline Lead Counting Shield & None, waste previously removed. \\
\hline Nondinary, Scrap Metal, Asbestos, PCB, Salvageable, Hazardous, Radioactive, Mixed, Unknown, Other \\
\hline None Available & \\
& \\
\hline Housekeeping Site Before Closure Activities & \\
& Current Site Condition \\
\end{tabular}

Current Site Description/Observations: Waste was previously removed. No waste remains onsite.

X No Further Action Required at Housekeeping Site

Reed J. Poderis, CEM

SIGNATURE APPROVED $\quad 8 / 10 / 05$

Corrective Action Coordinator/Designee

Signature

Date 


\section{APPENDIX C:}

\section{NATIONAL ENVIRONMENTAL POLICY ACT EVALUATION CHECKLIST}


Closure Report - CAU 286

Section: Appendix C

Revision: 0

Date: August 2005

THIS PAGE INTENTIONALLY LEFT BLANK 


\section{U.S. DEPARTMENT OF ENERGY \\ NATIONAL NUCLEAR SECURITY ADMINISTRATION NEVADA SITE OFFICE NEPA ENVIRONMENTAL EVALUATION CHECKLIST}

\begin{tabular}{|c|c|c|}
\hline \multicolumn{2}{|c|}{$\begin{array}{l}\text { FOLLOW ATTACHED PROCEDURES FOR COMPLETING CHECKLIST } \\
\text { A. Project/Activity Title (Attach a brief description of proposed project) } \\
\text { Housekeeping Sites Closure/Cleanup Activities (CAUs 286, 390, \& 395) }\end{array}$} & \multirow[t]{2}{*}{\begin{tabular}{|l|} 
Date \\
04/26/2005 \\
Anticipated Start Date \\
\end{tabular}} \\
\hline $\begin{array}{l}\text { Project Location } \\
\text { NTS, Various Areas }\end{array}$ & Proposed By (if other than NNSA/NSO) & \\
\hline $\begin{array}{l}\text { NNSANSO Line Management Organization } \\
\text { Environmental Restoration }\end{array}$ & \multicolumn{2}{|c|}{$\begin{array}{l}\text { NNSA/NSO Project/Program Manager } \\
\text { Sabine Curtis }\end{array}$} \\
\hline
\end{tabular}

ENVIRONMENTAL CONSIDERATIONS: If any phase of the project/activity involves any of the following considerations, check yes and explain in project description. See NV-16A for consideration quidelines and examples.

\begin{tabular}{|c|c|c|c|c|c|c|c|}
\hline CONSIDERATION & YES & NO & UNK & CONSIDERATION & YES & NO & UNK \\
\hline WASTE & & & & AIR EMISSIONS & & & \\
\hline 1 Non-Rad Solid Waste & $\mathbf{x}$ & & & 1 Biological Material/Chemical Release & & $\mathbf{x}$ & \\
\hline 2 Hazardous Waste & $\mathbf{x}$ & & & 2 Dust/Particulate Matter & $\mathbf{x}$ & & \\
\hline 3 Low-level Rad Waste & $\mathbf{x}$ & & & 3 Explosives & & $\mathbf{x}$ & \\
\hline 4 Mixed Waste & $\mathbf{x}$ & & & 4 Diesel Generators & & $\mathbf{x}$ & \\
\hline 5 TRU/Mixed TRU Waste & & $\bar{x}$ & & 5 Open Burning & & $\mathbf{x}$ & \\
\hline 6 Wastewater (domestic/industrial) & & $\mathbf{x}$ & & & & & \\
\hline & & & & SITE LOCATION/OTHER & & & \\
\hline HAZARDOUS MATERIALS & & & & 1 Environmental Restoration Site (CAU) & $\mathbf{X}$ & & \\
\hline 1 Petroleum/Fuel (storage/use) & $\mathbf{x}$ & & & 2 Excavation/Land Surface Disturbance & $\mathbf{x}$ & & \\
\hline 2 Underground Storage Tanks & & $\mathbf{x}$ & & 3 Off road travel & & $\mathbf{x}$ & \\
\hline 3 Aboveground Storage Tanks & & $\mathbf{X}$ & & 4 Biological/Tortoise Resource Area & & $\mathbf{X}$ & \\
\hline 4 PCB's/Asbestos & & $\mathbf{x}$ & & 5 Cultural/Historic Resource Area & & $\mathbf{X}$ & \\
\hline 5 Pesticides/Herbicides & & $\mathbf{X}$ & & 6 Change in Existing Drainage Pattern & & $\mathbf{X}$ & \\
\hline 6 Radioactive Materials & & $\mathbf{X}$ & & 7 Impact to Environmental Monitoring System & & $\mathbf{X}$ & \\
\hline 7 Biological Materials/Simulants & & $\mathbf{x}$ & & 8 Unexploded Ordnance Area & & $\mathbf{x}$ & \\
\hline 8 Beryllium & & & $\mathbf{X}$ & 9 Noise & $\mathbf{X}$ & & \\
\hline 9 Chemical storage/use & & $\mathbf{X}$ & & 10 Radiation controlled area & $\mathbf{X}$ & & \\
\hline 10 Use of explosives/firearms & & $\bar{x}$ & & 11 Drinking water system involvement & & $\mathbf{x}$ & \\
\hline
\end{tabular}

DONOT TYPE OR WRITE BELOW THIS LINE. FOA ESHD USE ONLY.

B. Is the project/activity included in the final NTS EIS and the ROD or other NEPA document?
Yes
(complete Sections C, D, and E)
No
(complete Sections D, E, and F)

C. This project/activity is included in the NTS EIS/ROD (or other NEPA document) under the following section and page no.:

NTS EIS Volume 1, Appendix A, A.3.1.3 - Environmental Restoration Program; Industrial Sites Project

D. Does the proposed project/activity require any local, state, or federal permits or notifications?

Yes $\underline{X} \quad$ No

E. If, based on the project description and the preliminary environmental considerations noted above, the proposed action fits within a class of action listed in Subpart D of 10 CFR 1021, write in the space below, the paragraph number and short title from the appropriate table of contents of Subpart $D$, Appendix B, C, or D, for a CX, EA, or EIS. If the proposed action does not fit within any class of action, write "Not Listed" below.

F. NEPA COMPLIANCE OFFICER DETERMINATION OR RECOMMENDATION:

I have determined that the proposed activity as described in item $A$ above, has been adequately addressed in the document cited in item $\mathrm{C}$ for the purpose of NEPA. No further analysis or documentation is required pursuant to NEPA.

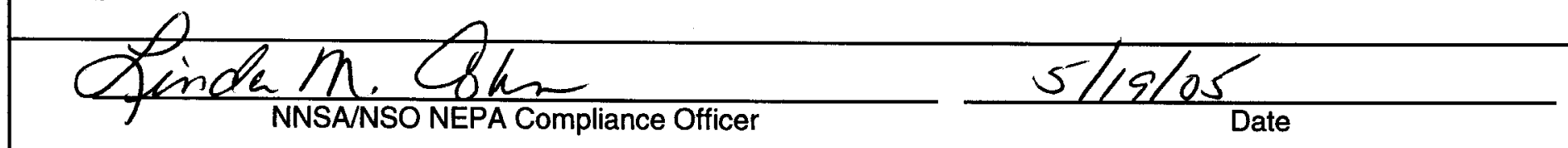




\section{CAUs 286, 390, \& 395 Housekeeping Sites Closure/Cleanup Activities}

\section{Project Description}

The purpose of this project is to remove various debris located at several Corrective Action Units (CAUs). The CAUs are housekeeping sites, located at the Nevada Test Site (NTS). CAU 286 is located in Areas 1, 2, 3, 4, 6, 10, and 18 and consists of twelve CASs. CAU 390 is located in Areas 9, 10, and 12 and consists of six CASs. CAU 395 is located in Area 19 and consists of ten CASs. A detailed list of the CASs and description of the CASs and descriptions is provided in the Federal Facility Agreement and Consent Order (FFACO) of 1996. Each CAU is listed below, with a brief description of the types of debris present in the CASs.

CAU 286 includes pieces of lead shielding in various locations. A pile of concrete is also included. Some of the waste may be radioactive. The lead material is hazardous. However, the majority of the lead material is salvageable for recycling.

CAU 390 includes asphalt, paraffin wax, and tar spills. One drum with several gallons of unknown liquid is also included. Some of the waste may be radioactive and/or hazardous/toxic.

CAU 395 includes concrete, oil, and asphalt spills. Several spills of unidentified materials are also included. Some of the waste may be radioactive and/or hazardous/toxic.

\section{Environmental Considerations}

W-1, Non-Rad Solid Waste: Any solid waste that may be generated from project activities will be disposed of at the NTS in a designated landfill.

W-2, Hazardous Waste: Several sites contain lead, PCB, or TPH-impacted and/or sanitary waste and soil. No other chemical hazards are known to exist. Personnel will be required to follow the safety procedures outlined in the Site Specific Health and Safety Plan and Job Hazard Analysis. Wastes will be disposed either on the NTS or offsite, depending on analysis results.

W-3, Low-level Rad Waste: Several sites are in a URMA, CA, or RMA. Radiologically impacted soil and debris in these areas may require disposal either at the Area 3 or Area 5 Radioactive Waste Management Sites.

W-4, Mixed Waste: Any waste which is classified as mixed waste will be disposed at the NTS in an approved mixed waste facility.

HM-1, Petroleum/Fuel (storage/use): Heavy equipment onsite will use petroleum fuel. No fuel will be stored onsite outside of the equipment. Absorbent pads will be used if equipment appears to be leaking petroleum.

HM-8, Beryllium: If any housekeeping site is determined to be in a legacy beryllium area, Industrial Hygiene will be contacted to provide guidance on how to minimize potential exposure 
to beryllium. This is in accordance with company procedure CM-0444.001-079, "Chronic Beryllium Disease Prevention".

A-2, Dust/ Particulate Matter: Some dust may be generated by excavation activities, but will be controlled as necessary by water spraying.

S-1, Environmental Restoration Site (CAU): These sites are included in the FFACO as CAU 286, 390, and 395 (See Project Description).

S-2, Excavation/Land Surface Disturbance: Equipment will travel off-road on previously disturbed areas. Equipment will also be used to help remove surface debris. Minor excavations may be required to remove stained soil at spill locations. All excavations will be performed under the appropriate permit.

S-9, Noise: Elevated noise levels may result from the operation of a backhoe and/or loader equipment. Personnel not directly involved with operation of this equipment will be kept back at least 15 feet while equipment is in use. The equipment operator will follow the instructions as directed in the Site Specific Health and Safety Plan.

S-10, Radiation Controlled Area: All CASs are in radiation controlled areas. All personnel onsite will have General Employee Radiological Training, at a minimum. Radiological Control Technicians will be onsite as required by Radcon. 
Closure Report - CAU 286

Section: Appendix D

Revision: 0

Date: August 2005

\section{APPENDIX D:}

\section{FFACO COORESPONDENCE}

D-1 
Closure Report - CAU 286

Section: Appendix D

Revision: 0

Date: August 2005

THIS PAGE INTENTIONALLY LEFT BLANK

D-2 
Ms. Janet Appenzeller-Wing

Acting Director, Environmental Restoration Division

Nuclear Security Administration

Nevada Site Office

P. O. Box 98518

Las Vegas, NV 89193-8518

RE: Approval of REQUEST TO TRANFSFER CORRECTIVE ACTION SITES (CAS) 18-99-08 AND 10-23-01 TO CORRECTIVE ACTION UNIT (CAU) 286, LEAD/CHEMICAL/SPILL SITES AND MATERIAL DUMPS

Dear Ms. Appenzeller-Wing:

The Nevada Division of Environmental Protection, Bureau of Federal Facilities (NDEP) staff has reviewed the request to transfer Corrective Action Sites (CAS) 18-99-08, Core in Boxes, located in CAU 167, Contaminated Materials and Trash Pits, and CAS 10-23-01, Metal Debris (RAD), located in CAU 210, Storage Areas and Contaminated Material, to CAU 286, Lead/Chemical/Spill Sites and Material Dumps. The request is hereby approved.

If you have any questions regarding this matter, direct them to Karen Beckley at (775) 687-9390, or Marcia Manley at (775) 687-9309.

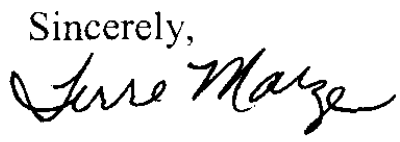

Terre A. Maize.

Chief

Bureau of Federal Facilities

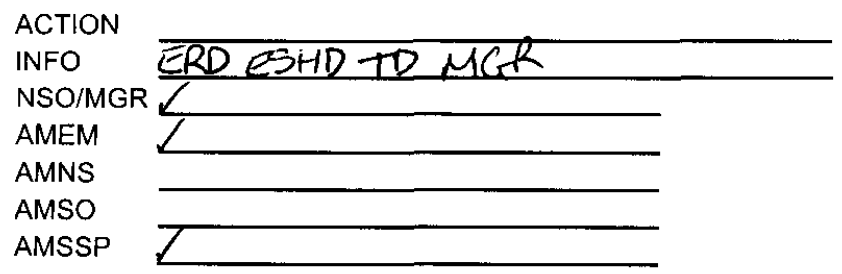


Ms. Appenzeller-Wing

April 15, 2004

Page 2

\section{$\mathrm{TAM} / \mathrm{MAM} / \mathrm{KKB} / \mathrm{DRE} / \mathrm{mm}$}

cc: Don Elle, NDEP LV

Karen Beckley, NDEP CC

S.M. Doty, EM Records Center, NNSA/NSO,

Las Vegas, NV

E.E. Shanholtz, DTRA/TDTNS, M/S 645, Mercury, NV

LTC P.M. Loomis, USA, DTRA/TDTNS, M/S 645, Mercury, NV

D.C. Loewer, DTRA/TDTNS, M/S 645, Mercury, NV

T.A. Lantow, DTRA/TDTNS, M/S 645, Mercury, NV

W.R. Griffin, BN/DTRA, M/S 645, Mercury, NV

R.L. Brittigan, DTRA/GC, Ft. Belvoir, VA

M.A. Demcko, DTRA/ALHK, Kirkland AFB, NM

J.L. Smith, BN, Mercury, NV

B.S. Bailey, S-N, M/S 439, Las Vegas, NV

B.C. Hoenes, S-N, M/S 439, Las Vegas, NV

G.M. Romano, S-N, M/S 439, Las Vegas, NV

K.A. Hoar, ESHD, NNSA/NSO, Las Vegas, NV

S.T. Curtis, ERD, NNSA/NSO, Las Vegas, NV

P.L. Hall, TD, NNSA/NSO, Las Vegas, NV 
Administration

DEPARTMENT OF CONSERVATION AND NATURAL RESOURCES

\section{DIVISION OF ENVIRONMENTAL PROTECTION}

(Las Vegas Office)

1771 E. Flamingo Road, Suite 121-A

Las Vegas, Nevada $\quad 89119-0837$

May 24, 2004

Monica L. Sanchez. Acting Director

Environmental Restoration Division

National Nuclear Security Administration

Nevada Site Office

P.O. Box 98518

Las Vegas, NV 89193-8518

Re: REQUEST TO TRANSFER CORRECTIVE ACTION SITES (CASs) 12-28-03, $02-$ 26-07 and 18-99-06 TO CORRECTIVE ACTION UNIT (CAU) 5000, ARCHIVED CORRECTIVE ACTION SITES

Dear Ms. Sanchez:

The Nevada Division of Environmental Protection, Bureau of Federal Facilities (NDEP) staff reviewed the additional information provided regarding this request to transfer three CASs to CAU 5000. Based on this review, NDEP agrees with the request to transfer the sites to CAU 5000.

If there are questions regarding this matter, please contact Don Elle at (702) 486-2874.

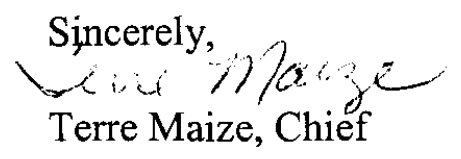

\section{TM/DRE}

cc: Ken Hoar, Director, ES\&HD, NNSA/NSO

Eric Shanholtz, Dhief, DTRA

Patti Hall, EM, NNSA/NSO

Wayne Griffin, BN/DTRA

Tiffany Lantow, DTRA/YDTON

Janet Appenzeller-Wing, kERD,NNSA/NSO

S. T. Curtis, ERD, NNSA/NSO

Karen Beckley, NDEP-CC

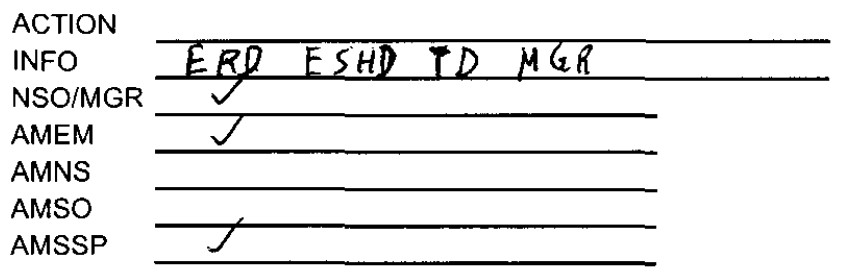




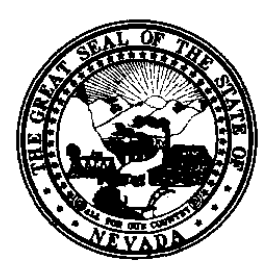

DEPARTMENT OF CONSERVATION AND NATURAL RESOURCES

\section{DIVISION OF ENVIRONMENTAL PROTECTION}

Las Vegas Office

1771 East Flamingo Road, Suite 121-A

Las Vegas, Nevada 89119-0837

December 2, 2004

Robert M. Bangerter, Acting Director

Environmental Restoration Division

National Nuclear Security Administration

Nevada Site Office

P.O. Box 98518

Las Vegas, Nevada 89193-8518

Re: Request to Transfer Corrective Action Sites (CASs) CAS 04-26-02 and 02-26-01 from CAU 286 to CAU 5000

Dear Mr. Bangerter:

The Nevada Division of Environmental Protection (NDEP) has reviewed the information submitted in support of transferring CASs 04-26-02 and 02-26-01 from CAU 286 to CAU 5000. NDEP concurs with the proposed transfer of CASs.

At each of the CASs, lead sheeting is contained within concrete; therefore, no environmental impacts or hazards were identified with leaving lead sheeting in place.

On November 10, 2004, NNSA/NV, NDEP, and Bechtel Nevada representatives visited each site and observed the lead sheeting - observations made during the visit are consistent with the information and assessment submitted to support the transfer of CASs to CAU 5000.

If you have questions regarding this issue, please contact Don Elle at (702) 486-2874, or John Wong, at (702) 486-2866.

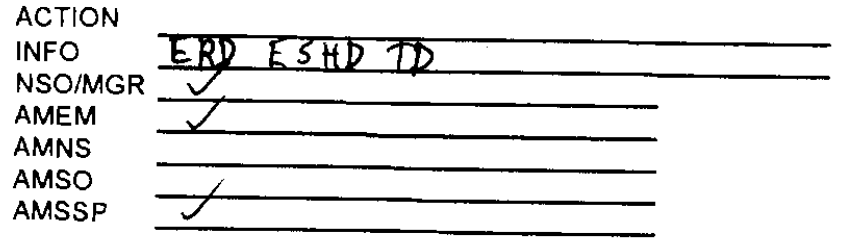


Robert M. Bangerter

Page 2

December 2, 2004

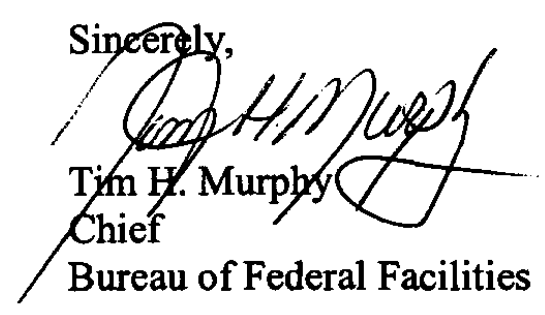

\section{THM/DRE/JAW}

cc: Ken Hoar, Director, ES\&HD, NNSA/NSO

E.E. Shanholtz, DTRA

D.C. Loewer, DTRA

T.A. Lantow, DTRA

W.R. Griffin, DTRA

P.L. Hall, TD, NNSA/NSO

J.L. Appenzeller-Wing, ERD, NNSA/NSO

S.T. Curtis, ERD, NNSA/NSO 
LEO M. DROZDOFF, Administrator (775) $687-4670$

Administration

Facsimile (775) 687-5856

Water Quality Planning

Water Pollution Control

Facsimile (775) 687-4684

Mining Regulations and Reclamation Facsimile (775) 684-5259

Las Vegas Office Facsimile (702) 486-2863
STATE OF NEVADA

KENNY C. GUINN

Governor

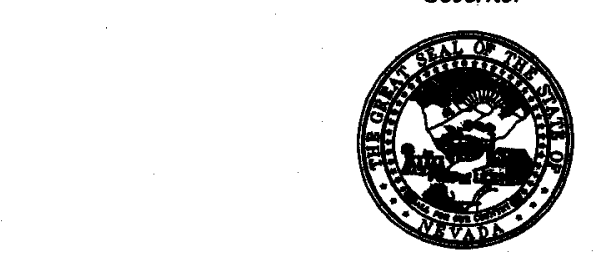

DEPARTMENT OF CONSERVATION AND NATURAL RESOURCES

DIVISION OF ENVIRONMENTAL PROTECTION

Las Vegas Office

1771.E. Flamingo Road, Suite 121-A

Las Vegas, Nevada 89119-0837

(702) 486-2850

May 24, 2005
ALLEN BIAGGI, Director Air Pollution Control Air Quality Planning Facsimile (775) 687-6396

Waste Management Facsimile (775) 687-6396 Corrective Actions Facsimile (775) 687-8335 Federal Facilities Facsimile (702) 486-2863 Webpage http://ndep.nv.soy

Robert M. Bangerter, Acting Director

Environmental Restoration Division

National Nuclear Security Administration

Nevada Site Office

P.O. Box 98518

Las Vegas, Nevada 89193-8518

Re: Request to Transfer Corrective Action Sites (CAS) CAS 18-99-08 and CAS 10-23-01 from CAU 286 to CAU 5000

Dear Mr. Bangerter:

The Nevada Division of Environmental Protection (NDEP) has received the request to transfer CAS 18-99-08 and CAS 10-23-01 from CAU 286 to CAU 5000. Considering the historical significance of the areas with respect to the Sulky Plowshare Project and atmospheric tower fragment (remains of atmospheric testing tower), respectively, NDEP concurs with the proposed transfer of CAS 18-99-08 and CAS 10-23-01 to CAU 5000, Archived Corrective Action Sites.

If you have questions regarding this issue, please contact Don Elle at (702) 486-2874, or John Wong, at (702) 486-2866.
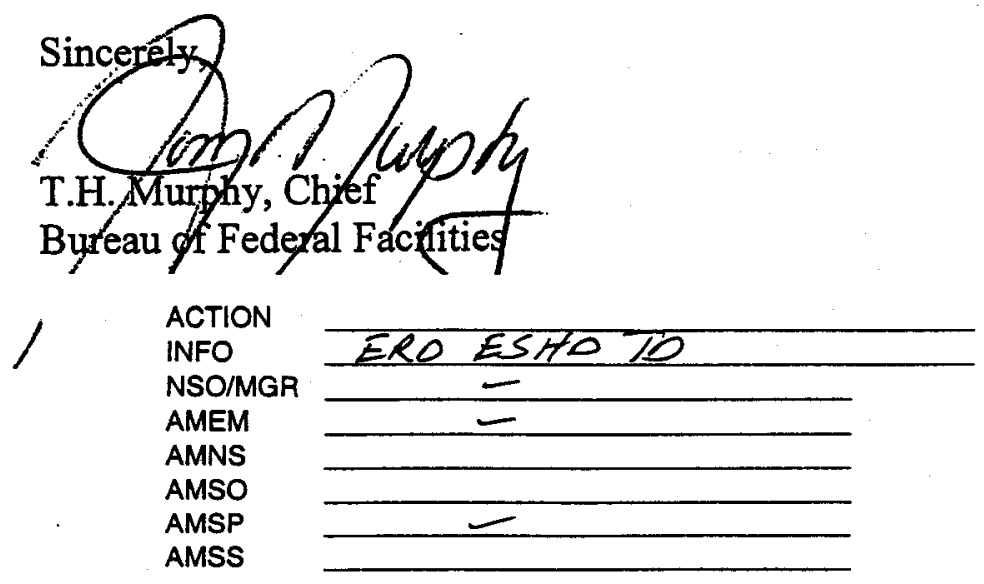
Robert M. Bangerter

Page 2

May 24, 2005

THM/DRE/JAW

cc: Ken Hoar, Director, ES\&HD, NNSA/NSO

E.E. Shanholtz, DTRA

D.C. Loewer, DTRA

T.A. Lantow, DTRA

W.R. Griffin, DTRA

P.L. Hall, TD, NNSA/NSO

J.L. Appenzeller-Wing, ERD, NNSA/NSO

S.T. Curtis, ERD, NNSA/NSO 
Closure Report - CAU 286

Section: Distribution

Revision: 0

Date: August 2005

\section{LIBRARY DISTRIBUTION LIST}


Closure Report - CAU 286

Section: Distribution

Revision: 0

Date: August 2005

THIS PAGE INTENTIONALLY LEFT BLANK 


\section{LIBRARY DISTRIBUTION LIST}

U.S. Department of Energy

National Nuclear Security Administration

Nevada Site Office

Technical Library

P.O. Box 98518, M/S 505

Las Vegas, NV 89193-8518

U.S. Department of Energy

Office of Scientific and Technical Information

P.O. Box 62

Oak Ridge, TN 37831-0062

Southern Nevada Public Reading Facility c/o Nuclear Testing Archive

P.O. Box 98521, M/S 400

Las Vegas, NV 89193-8521

Manager, Northern Nevada FFACO

Public Reading Facility

c/o Nevada State Library \& Archives

Carson City, NV 89701-4285
1 (Uncontrolled)

1 (Uncontrolled, electronic copy)

2 (Uncontrolled, electronic copies)

1 (Uncontrolled, electronic copy) 
Closure Report - CAU 286

Section: Distribution

Revision: 0

Date: August 2005

THIS PAGE INTENTIONALLY LEFT BLANK 